\title{
Is Participation Rooted in Colonialism? Agricultural Innovation Systems and Participation in the Netherlands Indies
}

\author{
Harro Maat
}

\begin{abstract}
1 Introduction
Public participation in scientific agenda-setting and technical decision-making has a prominent place on the agenda of Science and Technology Studies. The many studies have pointed out that involvement of citizens in scientific and technological activities with a notable impact on the way people live is an issue of democratic principle as well as making the right combination of different forms of expertise. Policymakers therefore have to look for implementation frameworks that increase public accountability and allow for appropriate management of available knowledge sources. Experience and findings in the academic field of Development Studies and among international development agencies, have moved along a similar path.
\end{abstract}

But Science and Technology Studies and Development Studies also show differences. One such difference is the relatively strong emphasis in Science and Technology Studies on 'downstream' processes. Science and Technology Studies' scholars critically follow the institutions of science, technology and policy in their attempts to involve a wider public (Irwin 2006). Studies on public engagement in Development Studies typically work 'upstream'. There is a strong focus on concepts and creation of methods to exploit the democratic potential of communities (Cooke and Kothari 2001). Despite such differences, it is clear that cross-linkages between the fields of Science and Technology Studies and Development Studies are fruitful and open up new insights (Leach et al. 2005).

One of the arguments developed in this article is that a historical perspective should be added. History contains many useful examples of public participation in scientific agenda-setting and technical decisionmaking. More than mere illustrations, historical cases also enfold conceptual questions. What is argued here, is that linking participation to issues (rather than to notions of citizenship) creates a better insight in the variety of ways in which science, technology and society interact. $A$ second conceptual point made in this article, is that an innovation systems approach creates more clarity on how and where issue-driven participation articulates.

What an innovation system is and how it relates to the issue-driven participation is explained first. The connection between innovation systems and participation is illustrated with historical material from the agricultural innovation system of the former Netherlands Indies (now Indonesia). Colonialism generally is not associated with public engagement and democratic principles. Nevertheless, the conclusion from this article is that developments in colonial innovation systems can contribute to present day reforms of innovation systems in developing countries.

\section{Innovation systems and participation}

The innovation system concept emerged from the work of institutional economists searching for factors of economic growth beyond the supply-and-demand mechanism. Technological change, as an economic growth factor, was considered to emerge from an interacting set of elements - research activities, technological experiments, formal education, development of skills, etc. These activities sometimes are located in specialised and separated 
environments, like a private laboratory or public research institute. They can be integrated within broader arrangements, like education facilities. Or they take place on-the-spot, like adjustment and fine-tuning of processes or skills training. All elements together form the innovation system (Nelson and Rosenberg 1993).

An innovation system is, first, a descriptive device. Besides institutional economists, economic historians and historians of science and technology picked up the notion to analyse changing interactions between science, industry, government and other actors. These studies point out that innovation systems emerged in the late nineteenth century and became a significant factor in most countries during the first decades of the twentieth century.

Second, the innovation systems concept serves various analytical purposes. One element, implied by the word 'systems', is the internal logic. Although 'system' is hardly used in a strict interpretation (as in cybernetics), it does raise the question about dominant actors and steering options. In many cases, a government tries to take up such a role. But even in, for example the agricultural sector in the Netherlands, where the government traditionally has a firm grip on innovation, it does not imply that the government is in all cases the first mover or plays a role in every part of the innovation system (Maat 2003a). And, to remain with the Dutch example, the industrial sector, although overlapping with agriculture, gives a very different picture with a much less prominent role for the government (Faber 2003).

A related point is the geographical 'location' of innovation systems. Through legal restrictions and subsidies, governments often favour national innovators, thereby strengthening ties between national actors. ${ }^{1}$ But as the example from the Netherlands above implies, within a country one can distinguish several innovation systems and most, if not all, innovation systems show transnational connections.

More recently, the innovation systems' notion has been taken up in the context of development studies, focusing mainly on agriculture. The variety of activities within the agricultural sector in developing countries is bringing in actors with very different backgrounds. Activities to incorporate innovation within the sector show a similar diversification. The concept is considered a useful means to realise how current developments in relation to knowledge and tools in agriculture can be understood. $A$ focus on innovation systems therefore creates insight into barriers and opportunities for further enhancement of innovation in agriculture (World Bank 2007).

How does public participation relate to the innovation systems concept? Within an innovation system, the 'wider public' usually gets translated into 'end-users', for example farmers when it concerns agricultural innovation systems. In a development context, this can be further specified as those who live and work in adverse agro-ecosystems (the rural poor or resource-poor farmers). Including participation in the innovation systems approach implies a more focused analytical scope. The general idea that innovation is a result of shared effort is specified to the question if and how end-users are involved. An example is a study by Hall and Nahdy (1999) of the agricultural research institutes in Uganda that have adopted the participation agenda, but nevertheless face huge difficulties in its implementation.

Obstacles to participation are rarely caused by a single actor in the system. Within the same Ugandan context, the programme to introduce so-called Farmer Field Schools, a tool to enhance farmer participation, appeared to have in-built barriers, due to arrangements made among various actors, including international donors (Isubikalu 2007). Besides looking at the role of particular institutions or specific participatory methods to increase the involvement of end-users, the analysis might also be focused on the 'systems conditions' that favour (or impede) the uptake of a particular innovation, like for example biotechnology (Chataway 2005).

As this last example implies, an innovation systems approach broadens the participation agenda by including questions about the uptake of particular technologies and how 'user-friendly' innovation systems are. This not only expands the analytical focus, it also raises a conceptual problem. The participation debate, particularly within the field of Development Studies, is framed exclusively around notions of citizenship and democracy. These concepts and their translation in approaches and methods are discussed intensively (Mosse 2005; Cooke and Kothari 2001). And although economic principles and material conditions are acknowledged as important factors, theoretical framing of the participation debate focuses primarily on 
elements like 'dialogic political methodologies' (Mohan and Hickey 2005: 69), 'democratic spaces' (Cornwall 2004) or a 'radicalized notion of citizenship' (Hickey and Mohan 2005: 12). Such theoretical framings ignore the role of innovation and technology (material processes in general) in participatory processes. Moreover, the notions of citizenship and democracy are problematic in itself.

Marres (2005) shows how most participation agendas build on idealised notions of democracy and the public. These notions are particularly problematic given the fragmented yet global nature of present day politics. ${ }^{2}$ Following Ulrich Beck's notion of 'subpolitics', she shows how many decisions are made outside, below or above, the traditional political fora of the nation-state. Understood as a more general process, subpolitics represent a 'displacement of politics'. By working out a pragmatist political philosophy and several empirical cases, she concludes that issues are the main driver for political displacement. Issues are not brought into political arenas but political arenas emerge around issues. Consequently, participation is also a process that works out differently depending on the issue at stake. Issues, Marres argues, 'deserve to be appreciated as occasions for political democracy: it is issues that necessitate public involvement in politics, and such involvement is dedicated to their settlement' (Marres 2005: 136).

An issue-centred perception of political processes is a useful way to highlight the political dimensions and participatory potential of an innovation systems perspective. As Chataway and Smith (this IDS Bulletin) argue, looking at participation through an innovation systems perspective blurs the distinction between an 'entitlement view' and a 'productivity view'. Focusing on issues at the core of political processes creates a window for technology, and material processes in general. The innovation systems approach is an appropriate notion to see where issues (i.e. politics from below) are likely to lock on to processes of technological change set in motion by other (outside) actors in the innovation system. One example is given by Richards (this IDS Bulletin), showing that the very act of acquiring an innovation (like appropriate seed material) can have participatory effects. Below, we will see how this works out in a colonial agricultural innovation system. Colonial history brings out some interesting cases of issuedriven participation.

\section{Participation and history}

Participatory approaches in Development Studies have a troublesome relationship with technology. The participation agenda of creating public spaces where reason and justice thrives, is generally set against topdown implementation of development. Introduction of Western technology is often assumed to have an inherent top-down characteristic. Top-down hierarchical processes and technocracy are basically considered as the same (bad) phenomena. ${ }^{3}$ The idea that the creation of public spaces for free deliberation is a counterforce to top-down bureaucracies and technocratic tendencies originates in the philosophical tradition of the Frankfurt School, particularly the work of Jürgen Habermas (Wagner 1994). Because technocracy and bureaucracy are most dominant in Western ('high modern') societies, Western technology (development projects in general) brought to developing countries is seen as a Trojan Horse, by which the same technocratic (and bureaucratic) principles are pushed on the developing world. In line with Habermas' theory, participatory approaches, emphasising informality and personal relationships ('life-world'), are considered a counterforce against the 'systemic arrangements' of the development orthodoxy. ${ }^{4}$

Critique on technocratic tendencies in international development often comes in the form of historical accounts. The origin of the participatory movement in international development is generally set in the 1970s. Participatory approaches in international development were a response to and protest against the colonial and early post-colonial development programmes (Cornwall 2000; Hickey and Mohan 2005). Indeed, development aid in the 1950s and 1960 s was generally put in terms like 'technical assistance' and 'transfer of technology', and most projects showed clear hierarchical structures with aid workers and scientists trained in the USA and Europe on top. The 1970s was the period that gave birth to an alternative approach. This, it is suggested, was a turning point in history.

Contrasts between old and new usually work well as a normative argument. From a historiographic viewpoint such contrasts are very problematic. When participation in development is understood as inclusion of the public based on individualised notions of agency and citizenship, the late colonial initiatives and early international development programmes indeed show a glaring void. Colonial administrations 
and the development institutes in the 1950s and 1960s worked with a different notion of development. For them, development aimed at national economies rather than individuals. Poverty was primarily seen in terms of Gross Domestic Products and much less as a state of individuals. It took a major development institute, the World Bank, until the late 1960 s before that emphasis was changed (Finnemore 1997). To make sense of participation in history requires a serious effort to understand what the notion might imply in different periods of time rather then judging events in the past from current ideas about what is, or ought to be.

Writing a full history of participation, if such an endeavour would at all be possible, is beyond the scope of this article. ${ }^{5}$ What is suggested here is that late colonial history provides some interesting examples of participation, perceived as the settlement of issues within an innovation system. The case presented here is the agricultural innovation system in the former Netherlands Indies.

\section{The colonial agricultural innovation system}

As noted above, in most countries a focus on innovation in more systematic forms emerged in the late nineteenth century. The same can be said about the Netherlands Indies. During the 1880s, sugar planters, suffering from economic depression and an epidemic cane disease, set up research stations to improve the cultivation and processing of cane. Although privately funded, the stations cooperated with the Botanical Garden, a public institute that included research laboratories in botany and chemistry. The example of the cane planters was soon followed by plantation owners working with other cash crops, such as tobacco, tea and rubber. The community of plantation owners and managers was a relatively small group of well-educated Europeans. The exchange of demands for, and availability of, technology was well organised through journals, meetings and personal contacts (Maat 2003b).

In the late 1890s, the colonial government set up a similar system for the cultivation of food crops. One reason for the government to do so was the staggering economy in previous years. However, together with economic recession, the colonial administration had to face growing civil unrest, especially among the Javanese peasantry. This came out, for example, in a sharp rise of cane-burnings, a form of protest that 'was grounded in the discontent born of insecurity' (Elson 1979: 226). Official investigations into the causes of the unrest acknowledged this indirectly by pointing out that the colonial administration had failed to address the needs of the rural population (de Jong 1998: 350). This critique was turned into new measures, first with the creation of so-called demonstration fields. On these fields, administrators, advised by staff from the colonial Botanical Garden, had to show how agricultural tools and methods could be optimally applied. Besides being beneficial to farmers, the demonstrations were also supposed to instruct administrators themselves, primarily the local leaders. In 1899 there were in total four demonstration fields close to a major village in different parts of Java. In 1907 there were about ten such fields scattered over the islands Java and Madura (Maat 2001).

In the first decade of the twentieth century, research and education facilities were added. In 1903, an Agricultural School was opened in Bogor (the colonial name was Buitenzorg) next to the Botanical Garden where the Javanese leaders could receive agricultural training. A year earlier the colonial administration had asked the director of the Botanical Garden, Melchior Treub, to write a proposal for a Department of Agriculture (DoA). The existing Botanical Garden and its research facilities were to form the core of the DoA. More research on food crops, particularly rice, was the main ingredient. Treub proposed three major areas of study. The first was research on the rice plant in its various stages. 'The demands and peculiarities of the different paddy species and varieties have to be checked on these points. This research is combined with local expert judgement in different parts of Java regarding soil and climatic conditions' (Treub 1902: 13). The other two research themes were pest control and soil analyses, the latter aimed at opening up new land for rice production. In 1905 the DoA became effective, headed by Treub.

Where Treub set out the research agenda, the political justification of the DoA in Dutch parliament, given by the minister of colonies, hinted at the wider social welfare issue. The minister stated that 'prevention of crop failure and similar disasters is not enough, but first of all serious effort must be put in augmentation of cultivation and bigger production, in order to supply the ever increasing population with sufficient food' (Idenburg 1904: 405). Treub's proposal was implemented without major 
modifications. The research on rice and other food crops was put under a specialised Experiment Station for Rice and Second Crops. A researcher was appointed for each of the themes.

A few years after the start of the DoA, the performance of the institute was brought into question. The initiative to create the institute formed part of a series of (rather late) responses to the economic and social instability in the colony. One other initiative was a further investigation of the economic situation of the local population. The chair of the committee leading the investigation,

H.E. Steinmetz, criticised the demonstration fields of Treub's department. His main objection concerned the supervision of the fields by local leaders. As members of the elite, these leaders took little interest in the 'mundane' activities of rice farmers. Similar criticism was expressed by one of Treub's direct colleagues, Jacob van Breda de Haan. On leave in the Netherlands, he advised the Minister of Colonies to educate young Javanese who were interested in agriculture (and not just the elite) and put them in charge of demonstrations, supervised by European agronomists (van den Doel 1994: 230-32).

The colonial government took the advice seriously and informed Treub. But Treub was against the idea and made a counterproposal. Again he stressed the need for more scientific research. 'Three conclusions that can be drawn from contemporary studies and examinations with specific significance for practice are: (1) there is a bigger chance than expected that improved varieties will be found soon; (2) the limitations of selection can be assessed better; (3) the consequences of crosses can often be predicted with mathematical precision' (Creutzberg 1972: 347-8). He therefore requested to create a new 'selection garden' and build a model rice farm. The first was to select the best rice varieties, the latter to discover factors leading to yield maximisation.

The head of the Directorate of Agriculture in the Netherlands, Herman Lovink, was asked to review the proposal. Lovink saw no harm in the selection garden but was not convinced by the plan to build a model farm. In his response he first presented some of the experiences with agricultural extension in the Netherlands and then drew the conclusion that barriers for progress and deficiencies in knowledge must be sought on the farms together with the farmers. According to Lovink, an experimental rice farm will not reveal real shortcomings, and will only have scientific value and hardly any practical use. 'It therefore seems that Professor Treub is not taking the right position. The question is not what maximum possible amount of rice can grow on a certain area, but how it will be possible, once acquainted with rice cultivation as conducted by the Javanese, to increase together with the Javanese farmer his rice yields economically, taken into account his development, workforce and his capital' (Creutzberg 1972: 387). Lovink wrote this in July 1909 and in December of the same year, he was appointed to the position of Treub, who was repatriated because of illness.

The different views between the two directors can be explained partly by their backgrounds. Treub was from of a successful generation of biology students. One of his study partners at Leiden University in the late 1860s was Hugo de Vries, who later became one of the rediscoverers of Mendel's laws. Treub, and Dutch biologists in general, including those working in the colonies, were well informed about international developments in biology and genetics, participated in conferences and published internationally. With his fellow biologists and many other academics he considered too much focus on science applications as a threat to the purity of science. ${ }^{6}$ Lovink was from the 'applied' side. He had combined school and work from a very early age and became director of a consultancy firm for reforestation in his mid-twenties. He turned the then small company into one of the biggest Dutch agroforestry consultants. His qualities were noticed by the Minister of Trade and Industry, who invited him in 1901 to lead the agricultural department. Prior to his appointment in the Indies, Lovink had reorganised the Dutch agricultural services, research and education institutes to make them most effective for Dutch agriculture. He was, in retrospect, the architect of the Dutch agricultural innovation system (Maat 2003a).

Under Lovink's leadership, the model farm, as proposed by Treub, was never accomplished. He opened the agricultural school for all male students, regardless of background. The Dutch and Javanese functionaries together formed the colonial Agricultural Extension Service, established in 1911. The extension work also comprised supervision over new agricultural schools in different parts of Java and an increasing number of demonstration fields, moved from a central location near larger villages to rural areas. These fields were not just windows for innovation, but mechanisms to get information 
about local farming conditions, bottlenecks and possible improvements.

The question about entry conditions for the agricultural training was related to a wider issue, the colonial education system. Education was fiercely debated in those days. The educational system in the Netherlands Indies was by and large separated between primary schools, with instruction in local languages, and secondary (middle level and higher) schools, where mastering the Dutch language was a requirement. ${ }^{7}$ The Dutch orientation became problematic, especially in relation to the Javanese elites and the 'creole' class of Indo-Europeans. These groups usually mastered Dutch sufficiently and urged for considerable expansion of the (Dutch) secondary and tertiary school types. This would provide them access to the higher level positions in society in general, and the colonial administration in particular. Precisely that last thing was something the Dutch rulers tried to prevent. By restricting the growth of the middle and higher level (Dutch) schools, and at the same time restricting entry of these groups in the administration, colonial rule remained exclusively in the hands of Dutch (Netherlands-born) administrators. The frustration this evoked was a major cause of the emerging nationalistic movements in the early twentieth century (de Jong 1998: 383-6). But the colonial education system was problematic for another reason.

The language created an extra hurdle, making the step from primary to secondary schooling an almost unbridgeable gap for both the rural and urban population. Secondary schools with instruction in local languages did not exist, making it nearly impossible for the majority of local Indonesians to continue education. The difference in language plus the cultural gap between local elites and rural population also blocked a 'downward' flow in the system, either in terms of appointment of well-educated school teachers or tuning of teaching materials and methods. Lovink's concerns were not only about supervision of demonstration fields, but included the entire educational system. In several letters to the GovernorGeneral, he argued that the real problem of food crop production lay in the education of the Javanese farmers. He proposed to include agronomy lessons in the primary school curriculum, train school teachers in agriculture and make sure that the agricultural advisers from the extension service stayed in touch with the schools (Creutzberg 1972: 391-420).
Lovink explicitly stated that the approach to agricultural innovation on Java should not be any different from those applied in Europe. ${ }^{8}$ Of course conditions on Java did not allow him to copy what he had done in the Netherlands. What has become clear, however, is that the overall political issue of improving the situation of the (primarily rural) population on Java, in response to economic and social instability, worked through at the level of the agricultural innovation system in the Netherlands Indies. The data suggests (further evidence to that is given in the next section) that addressing the needs of the indigenous farmers was taken up through the creation and further modification of the innovation system.

\section{Testing the 'sugar model'}

In 1918, Lovink was repatriated and replaced by Joan Sibinga Mulder. The new Director-General arrived in a turbulent period. The First World War had just ended and the Netherlands Indies, particularly Java, faced serious food shortages. The dependence on rice imports had become increasingly problematic during the war. Shipping routes were unsafe and available tonnage strongly reduced.

One of the strategies of the DoA to diminish rice imports and reduce the risk of famines, was to broaden the diet of the Javanese people. A crop that emerged as a very important food crop in the 1910s was cassava. Introduced in Java probably in the early 1800s, it covered only about 2 per cent of the cultivated area in 1880, but was one of the top three food crops by the end of the 1910s. The increase of cassava production in this period was a result of a range of factors. The opportunities for export increased after tapioca manufacturing expanded considerably in the late 1890s, although even at their peak in the 1920 s cassava exports only covered 15 per cent of total production. The balance was used for consumption.

The growing popularity of cassava was probably caused by two favourable characteristics of the crop. One is its tolerance for dry and adverse soil conditions, making the crop a good alternative in dry years. The other is the extended period of harvesting. From the moment a cassava plant reached a certain size, its tubers could be dug up when needed. The inclusion of cassava in the diet of the Javanese was more or less an 'endogenous' process. In the 1910s the government stimulated cassava consumption through various measures, but only after cassava 
production was well established (van der Eng 1996). As a result, cassava and other alternatives to rice received more attention from the researchers in Buitenzorg. ${ }^{9}$ But incremental changes were not enough to face an acute crisis.

The crisis of the immediate postwar food shortages made projects with direct and clearly visible effects attractive. Sibinga Mulder thought he had found such a quick solution. He had started his career in the sugar industry on Java. Arriving as a technician on a plantation in 1887, he quickly made his way up in the cane sector. In the years before he was appointed head of the DoA, he was based in the Netherlands and had made several trips for the Ministry of Colonies. In January 1919 he proposed to the Governor-General of the Indies that he start an experiment with mechanised rice farming on Sumatra. On one of his trips he had seen large rice farms in California, USA, and considered it a useful introduction to the Indies. If the experiment succeeded, the only thing the government would have to do would be 'to urge the spirit of capitalist agricultural enterprise and to provide land and water concessions without the usual formalities' (Creutzberg 1973: 248).

To get more information on the rice systems in the USA, Sibinga Mulder sent one of his agronomists, M.B. Smits, on a study trip. In his report, Smits clarified that it was not very likely that mechanised rice farming would succeed in the Indies. The caution in the report is quite in contrast to the enthusiasm shown in the preface written by Sibinga Mulder (Smits 1920). Preparations and first activities had already started in the same year.

A flat area near the river Selatdjaran on Sumatra was selected for the experiment. In May 1920, about 700 ha of land was protected by a dyke $11 \mathrm{~km}$ long. Problems with water management and clearing of the land caused some delay, and in March 1921, 50 ha was sown with rice. A lack of water and an abundance of rats made the engineers decide to plough the crop before maturation and to sow the plot anew, adding another 70 ha. That season, the rats were helped by a bug (Leptocorisa acuta Thunb.) and most of the crop was lost. In 1923, there was still no significant harvest and it was decided to stop the experiment after the 1923-4 season. The total costs were estimated at 1.3 million guilders. The same year Sibinga Mulder was removed from office
(Creutzberg 1972: 374). Official documents do not mention the failed experiment as a direct result.

Besides a technical experiment in rice production, the mechanisation scheme was also testing if a commercial system, similar to the one applied in the cane sector, could help food production. Political motives played an important role here as well. The sugar industry was a favourite target for the emerging nationalist movement to criticise colonial rule. Sugar cane was grown on land that was rented from local farmers, who usually planted rice on these fields. This, the critics argued, proved that the colonial rulers allowed Dutch entrepreneurs to exploit the soil at the cost of a starving population. Cane planters of course denied the negative effects of their activities. ${ }^{10}$ One of the proposals of the colonial government, fearing the Indonesian nationalists, was to reduce and limit the area grown with cane. Sibinga Mulder actively supported the lobby of the cane industry to prevent this (Taselaar 1998). Being in charge of the DoA was an opportunity for Sibinga Mulder to improve the image of the cane sector and, more generally, show that commercial agriculture was the right way forward. Besides the many technical difficulties, the industrial approach to rice farming also met resistance from within the DoA.

The agronomists from the Agricultural Extension Service had developed a specific view on how science could benefit food crop production. Smits was one of the earliest experts who published on this: in 1916, he wrote an overview of rice cultivation in the Indonesian archipelago. His main conclusion was that 'the intensity of agriculture does not primarily depend on the development and technical knowledge and skills of the farmer, but on the economic principles of the farm. [...] In general one can detect that, even if the native does not know anything about the yield of his farm, the intensity of the farm is in miraculous harmony with the economic conditions' (Smits 1916: 480). Just before his trip to California, Smits had published a major study about the future of food crop production in Indonesia. He argued that the way forward was to intensify existing farming systems. For Sumatra, the island where he was stationed, this implied intensification of dry (or upland) rice farming systems. Such dry systems were at the time the main form of rice cultivation on Sumatra, very different to Java where wetland (paddy) rice farming dominated (Smits 1919). 
Smits was certainly not the only one who expressed such views. It was the perception of many agronomists working on food crop production at the DoA. ${ }^{11}$ The need to get a proper understanding of existing farming systems was seen as a necessary first step for the introduction of new technology. For example, Dutch plant breeders were very active to improve the existing range of rice varieties. The 'farming systems studies' forced breeders and agronomists to be very specific on what they offered. 'The native farmer seeks in many areas for better varieties. It is a myth that he would be so conservative that he does not like better varieties, unless of course taste and price differences or other adverse characteristics make the better products of little extra economic value' (Vink and Scheltema 1925: 200)

The agronomists at the DoA had developed a technical approach, made possible by the organisational changes set in motion under Lovink's direction. This approach implied that through detailed analysis of local farming systems, the local needs were addressed. In other words, it is through the technical implementation of food crop improvement as developed in the colonial agricultural innovation system that participation emerged. There is no evidence that, in relation to food supplies, the overall objectives of the agronomists of the DoA were very different from what Sibinga Mulder had in mind. The differences were framed in technical terms, disguising (not eliminating) political factors.

Much later, Smits evaluated the mechanisation scheme once again. In the 1930s, there was another initiative to introduce mechanised agriculture, this time in the other colony of the Dutch, Surinam. Smits commented on the technical aspects as well as the approach taken. According to Smits, a major bottleneck for mechanisation was not the use of machinery as such, but the control of weeds. In climate zones with a clear dry season, the drought implies a thorough clearing of weeds. In humid tropical conditions as found in Indonesia and Surinam, plant growth was continuous and weeds a constant threat that could only be controlled by manual weeding. ${ }^{12}$ He ended his review with an argument against copying examples from other countries. 'When the issue of mechanised rice farming is addressed, one fully has to let go of the American example and set up an entirely new system, based on well-established indigenous experience. In doing so one can meet all the biological requirements of the rice plant' (Smits 1934: 629).

The issue of food security was played out in the Netherlands Indies first by Treub and Lovink, each having different views about the appropriate format for the agricultural innovation system. The two other players, Sibinga Mulder and Smits, clashed over the technical approach that had to be taken. Treub and Sibinga Mulder came with more or less precooked formats. Treub thought that creating research facilities was paramount, whereas Sibinga Mulder proposed an industrial approach to agriculture. Lovink and Smits advocated a 'contextual' view. Lovink emphasised the importance of education and creating the right channels for knowledge to flow in two directions. Smits emphasised the economic and technical complexities of local farming systems that demanded solutions that would fit these complexities.

\section{Colonial innovation systems and participation}

There is a growing body of literature providing evidence that the case of the agricultural innovation system in the Dutch colonial period, as presented here, is no exception. The common line of argument in histories of technology in the colonies is to emphasise interactions between colonial rule and technology in a deterministic way. Technology then is seen as the means through which European rulers exploited and controlled the local population. In many cases, the effect of certain innovations was indeed exploitation, not least because some technologies were employed deliberately for that purpose. Technology, however, has many shapes and can have various effects.

A study on African colonial settlement schemes shows that even within the context of rigidly disciplining projects, colonial experts learned to understand and appreciate local expertise (Bonneuil 2000). Another example refers back to the sugar case. On Java, the sugar research and technology was firmly controlled by the European planters, supporting the image of Western technology as a tool for Western domination. On Mauritius, however, sugar technology was affected by political pressure of disgruntled groups within the ethnically diverse population. Smaller sugar planters from Indian origin protested against quality controls. To prevent riots, cane breeders translated their 
demands in their breeding programmes (Storey 1997). In colonial Sierra Leone, post-First World War, food shortages resulted in food riots (against the Lebanese community, dominating rice trade) that were countered with the development of large intensive wetland rice schemes, with input from Indian experts (Richards 1986: 4-10).

These examples and the case material presented in this article show that an innovation systems perspective is an appropriate analytical tool to understand the different shapes that certain applications (or innovations) can take as a result of particular social and technical arrangements. Moreover, when participation is considered not as rooted in political ideals, but as an emergent phenomenon related to the settlement of issues, the participatory agenda comes out much clearer in relation to the organisation of innovation and technical change and the choice between various technological solutions. Colonial history provides a challenging area for case studies on issue-driven participation from an innovation systems perspective. Clearly, a colonial regime is far from the political ideal of democracy. In a colonial system, groups suffering from economic or social injustice have little other means to raise their voice than to protest, indirectly, or openly and violently. Colonial administrators are locked in the same oppressive system and have few other means to respond than to employ a politics of 'issue settlement'.

This brings us to the question of what these colonial cases can teach us in order to analyse and enhance participation and innovation in the present development debate. As the material shows, various actors within the colonial innovation systems voiced their concerns about certain approaches or applications in technical, rather than in political terms. Nevertheless, the issue-driven politics within the colonial innovation systems was clearly present. This came out at the level of leaders of institutes and departments, who had direct contact and discussion with administrative and political leaders, as well as at the lower levels of agronomists and researchers, showing commitment to the 'locality' they had become to know. A better understanding is needed about how responsiveness and operational flexibility in relation to issue politics plays out in the much more global character of the (agricultural) innovation systems that serve the international development agendas.

\section{Notes}

* I am grateful to reviewers for comments on an earlier version of this article and members of the Participatory Approaches and Up-scaling programme for the many discussions on technology and participation. I am especially grateful to Paul Richards for joint teaching on this topic and his detailed comments to this article. I also want to thank Diana Akullo and Chris Opondo for providing insight into 'their' East African innovation systems. Research for this article was supported by the Dutch Organisation for Scientific Research (NWO), grant No. 360-53-020

1 Governments and economic analysts often echo what Nelson and Rosenberg (1993) call a 'spirit of technonationalism', as can be detected in explanations of the rapid Asian industrialisation in the 1980s and 1990s.

2 However, she shows that the very same point was discussed in the 1920s between the American philosopher John Dewey and the journalist Walter Lippmann. One of the books from Lippmann's hand is Phantom Public, a title

aptly catching his unease with idealised notions of citizenship in political theory (Marres 2005: 182).

3 Cornwall (2000: 17) portrays the emerging participatory movement in the 1970s as follows: 'The welter of declarations that emerged in this period promised a decisive shift, away from topdown, technocratic and economistic interventions towards greater popular involvement in the development process'.

4 There are numerous references to Habermas in the participatory literature. For a critique on the dualism in his theory, see Wagner (1994: 188-90). For discussion on his more recent work in relation to globalisation and politics, see Marres (2005: 11-16).

5 One historical line runs through protestant religion back to the sixteenth-century Reformation (Henkel and Stirrat 2001).

6 The discussion about pure science versus applied science, the common phrasing in those days, formed an important ingredient in the debates about academic reform in the Netherlands (Maat 2001).

7 There were, of course, primary schools with instruction in Dutch, the European Elementary 
School (Europese Lagere School) and, separately, a Dutch Indies School and Dutch Chinese School.

8 In a letter dated 27 May 1911, he wrote: 'I can not deny that, as my understanding of life and work of the indigenous farmer increases, I become more convinced that the indigenous farmer, when approached the right way, is not any less susceptible for applying improvements on his farm than his European colleague' (Creutzberg 1972: 404).

9 Lovis Koch (1934), head of the breeding station in that period, wrote a dissertation on cassava selection

10 The question, if renting out land to and working for the sugar factories was really less attractive to

\section{References}

Bonneuil, C. (2000) 'Development as Experiment: Science and State Building in Late Colonial and Postcolonial Africa, 1930-1970', Osiris 15: 258-81

Chataway, J. (2005) 'Introduction: Is it Possible to Create Pro-poor Agriculture Related Biotechnology?', Journal of International Development 17.5: 1-14

Cooke, B. and Kothari, U. (2001) Participation: The New Tyranny?, London: Zed Books

Cornwall, A. (2004) 'Introduction: New Democratic Spaces? The Politics and Dynamics of Institutionalised Participation', IDS Bulletin 35.2: 1-10

Cornwall, A. (2000) Beneficiary, Consumer, Citizen: Perspectives on Participation for Poverty Reduction, Stockholm: Swedish International Development Cooperation Agency

Creutzberg, P. (ed.) (1973) Het Economisch Beleid in Nederlandsch-Indië; Capita Selecta: een Bronnenpublikatie 2 [The Economic Policy in the Netherlands Indies; Selected Readings; A Source Publication], Groningen: Commissie voor Bronnenpublicatie betreffende de geschiedenis van Nederlandsch-Indie (CBNI)

Creutzberg, P. (1972) Het Economisch Beleid in Nederlandsch-Indië; Capita Selecta: een Bronnenpublikatie 1 [The Economic Policy in the Netherlands Indies; Selected Readings; A Source Publication], Groningen: CBNI

de Jong, J. (1998) De Waaier van het Fortuin; De Nederlanders in Azië en de Indonesische archipel 1595-1950 [The Fan of Fortune; The Dutch in Asia and the Indonesian Archipelago], Den Haag: Sdu Uitgevers

Elson, R.E. (1979) 'Cane-burning in the Pasuruan Area: An Expression of Social Discontent', in
Javanese farmers than growing rice, is a debate kept alive by historians (Knight 1992).

11 The common methodology applied by the agronomist was labelled 'farm analysis' (bedrijfsontleding). These detailed descriptions of technical and economic factors leading to particular forms of production in a village usually ended with recommendations to improve these local farming systems.

12 The introduction of herbicides in the 1930s and 1940s changed the situation. Another advantage of a dry period is that the (muddy) top soil gets hard enough to carry the machines (Grist 1975: 198).

F. van Anrooij, D.H.A. Kolff, J.T.M. van Laanen and G.J. Telkamp (eds), Between People and Statistics. Essays on Modern Indonesian History, The Hague: Martinus Nijhoff

Faber, J. (2003) 'Het Nederlandse Innovatie Systeem, 1870-1990' [The Dutch Innovation System, 1870-1990], NEHA-jaarboek voor Economische, Bedrijfs- en Techniekgeschiedenis 66: 208-32

Finnemore, M. (1997) 'Redefining Development at the World Bank', in F. Cooper and R. Packard (eds), International Development and the Social Sciences: Essays on the History and Politics of Knowledge, Berkeley: University of California Press

Grist, D.H. (1975) Rice, 5th edn, London: Longman Hall, A. and Nahdy, S. (1999) New Methods and Old Institutions: The 'Systems Context' of Farmer Participatory Research in National Agricultural Research Systems. The Case of Uganda, ODI Network Paper 93, London: Overseas Development Institute Henkel, H. and Stirrat, R. (2001) 'Participation as Spiritual Duty; Empowerment as Secular Subjection', in B. Cooke and U. Kothari, Participation: The New Tyranny?, London: Zed Books Hickey, S. and Mohan, G. (2005) 'Towards Participation as Transformation: Critical Themes and Challenges', in S. Hickey and G. Mohan (eds), Participation - From Tyranny to Transformation?: Exploring New Approaches to Participation in Development, London: Zed Books

Idenburg, A.W.F. (1904) 'De Memorie van Toelichting op het Wetsontwerp tot Oprichting van een Landbouwdepartement in Ned. -Indië' [Explanatory Memorandum to the Bill for the Establishment of a Department of Agriculture in the Netherlands Indies], Tijdschrift voor het Binnenlandsch Bestuur 26: 394-417 
Irwin, A. (2006) 'The Politics of Talk: Coming to Terms with the "New" Scientific Governance', Social Studies of Science 36.2: 299-320

Isubikalu, P. (2007) Stepping-Stones to Improve Upon Functioning of Participatory Agricultural Extension Programmes. Farmer Field Schools in Uganda, Wageningen: Wageningen Academic Publishers

Koch, L. (1934) 'Cassaveselectie' [Cassava selection], PhD thesis, Landbouwhoogeschool, Wageningen, The Netherlands

Knight, R. (1992) 'The Java Sugar Industry as a Capitalist Plantation: A Reappraisal', Journal of Peasant Studies 19.3/4: 68-86

Leach, M.; Scoones, I. and Wynne, B. (eds) (2005) Science and Citizens: Globalization and the Challenge of Engagement, London: Zed Books

Maat, H. (2003a) 'Het Innovatiesysteem voor de Nederlandse Landbouw' [The Innovation System for Dutch Agriculture], NEHA-jaarboek voor Economische, Bedrijfs- en Techniekgeschiedenis 66: 233-62

Maat, H. (2003b) 'Techniek en het Koloniale Verleden' [Technology and the Colonial Past], in J.W. Schot, H.W. Lintsen, R. Oldenziel, M. Davids and G.P.J. Verbong (eds), Techniek in Nederland in de Twintigste eeuw, deel VII, Techniek en Modernisering; Balans van de Twintigste Eeuw [Technology in the Netherlands in the Twentieth Century, Part VII, Technology and Modernisation; Taking Stock of the Twentieth Century], Zutphen: Walburg Pers

Maat, H. (2001) Science Cultivating Practice; A History of Agricultural Science in the Netherlands and its Colonies, 1863-1986, Dordrecht: Kluwer Academic Publishers

Marres, N.S. (2005) 'No Issue, No Public: Democratic Deficits after the Displacement of Politics', PhD thesis, University of Amsterdam, The Netherlands Mohan, G. and Hickey, S. (2005) 'Relocating Participation within a Radical Politics of Development: Critical Modernism and Citizenship', in S. Hickey and G. Mohan (eds), Participation - From Tyranny to Transformation?: Exploring New Approaches to Participation in Development, London: Zed Books

Mosse, D. (2005) Cultivating Development. An Ethnography of Aid Policy and Practice, London: Pluto Press

Nelson, R.R. and Rosenberg, N. (1993) 'Technical Innovation and National Systems', in R.R. Nelson (ed.), National Innovation Systems: a Comparative Analysis, New York: Oxford University Press
Richards, P. (1986) Coping with Hunger. Hazard and Experiment in an African Rice-Farming System, London: Allen \& Unwin

Smits, M.B. (1934) 'Mechanische Rijstcultuur en haar Betekenis voor de Nederlandsche Koloniën' [Mechanical Rice Cultivation and its Relevance for the Dutch Colonies], Landbouwkundig Tijdschrift 46: 617-29

Smits, M.B. (1920) De Rijstcultuur in Noord-America met behulp van Mechanische Arbeid [The Rice Cultivation in North America Supported by Mechanical Labour], Batavia: Landsdrukkerij

Smits, M.B. (1919) De Voedselvoorziening van Nederlandsch-Indië [The Food Supply of the Netherlands Indies], Batavia: Vereeniging voor Studie van Koloniaal Maatschappelijke Vraagstukken

Smits, M.B. (1916) 'De Ontwikkeling van den Natten Rijstbouw' [The Development of Wet Rice Cultivation], Teysmannia 27: 469-83

Storey, W.K. (1997) Science and Power in Colonial Mauritius, Rochester: University of Rochester Press

Taselaar, A. (1998) De Nederlandse Koloniale Lobby. Ondernemers en de Indische Politiek, 1914-1940 [The Dutch Colonial Lobby. Entrepreneurs and Indies Politics, 1914-1940], Leiden: Research School of Asian, African, and Amerindian Studies (CNWS)

Treub, M. (1902) Schematische Nota over de Oprichting van een Agricultuur-Department in NederlandschIndië [Schematic Memorandum About the Establishment of an Agricultural Department in the Netherlands Indies], report, Buitenzorg van den Doel, H.W. (1994) De Stille Macht: Het Europese Binnenlands Bestuur op Java en Madoera, 1808-1942 [Silent Forces: The European Domestic Administration on Java and Madura, 1808-1942], Amsterdam: Bert Bakker

van der Eng, P. (1996) Agricultural Growth in Indonesia: Productivity Change and Policy Impact Since 1880, Basingstoke: Macmillan

Vink, G.J. and Scheltema, A.M.P.A. (1925) Overzicht van de Productiviteit der Sawahs voor Padi in de Residentie Semarang [Overview of the Productivity of Paddy Fields in the Semarang Residency], Buitenzorg: Landsdrukkerij

Wagner, P. (1994) A Sociology of Modernity; Liberty and Discipline, London: Routledge

World Bank (2007) Enhancing Agricultural Innovation. How to go Beyond the Strengthening of Research Systems, Washington DC: World Bank 